\title{
TOMATO SPOTTED WILT VIRUS IN SRI LANKA: EMERGING PROBLEMS OF TOSPOVIRUSES
}

\author{
Widana Gamage $\mathrm{SMK}^{* 1}$, Hassani-Mehraban $\mathrm{A}^{2}$ and Peters $\mathrm{D}^{2}$ \\ ${ }^{1}$ Department of Botany, University of Ruhuna, Matara, Sri Lanka \\ ${ }^{2}$ Laboratory of Virology, Wageningen University, 6708PB, Wageningen The Netherlands
}

Accepted: 19 February 2014

\begin{abstract}
Tomato spotted wilt virus (TSWV), the type species of the genus Tospovirus has long been reported infecting economically important horticultural crops such as tomato, groundnut, pepper, potato and soybean, all over the world. In Sri Lanka, characteristic tospovirus symptoms such as bud necrosis, axillary shoot proliferation and ring spots were observed on leaves of groundnut in Angunakolapalassa, and concentric rings on leaves and fruits of tomato, in Ambalantota and Gannoruwa. Sap extracted from both tomato and groundnut plants was serologically positive for TSWV infection in a double antibody sandwich enzyme-linked immunosorbentassay (DASELISA), but not for Groundnut bud necrosis virus (GBNV). Nucleocapsid (N) genes of both isolates were amplified in Reverse Transcription Polymerase Chain Reactions (RT-PCR) using primers specific for TSWV and GBNV. The sequences obtained showed $98 \%$ amino acid sequence identity to the $\mathrm{N}$ gene of the Brazilian isolate of TSWV-BR-01. This study confirms the presence of TSWV infecting groundnut and tomato in Sri Lanka.
\end{abstract}

Key words: DAS-ELISA, TSWV, Serology, RT-PCR

\section{INTRODUCTION}

The genus Tospovirus represents the only genus infecting plants within the family Bunyaviridae. The viruses of the other four genera of this family infect animals. The viruses of the genera Orthobunyavirus, Nairovirus and Phleobvirus are arthropod-borne, while those of the genus Hantavirus are spread by excretions of rodents. Some species infect cattle and humans after exposure to the transmitting vectors and cause serious diseases such as Rift valley fever, Hantavirus pulmonary syndrome and Crimean-Congo haemorrhagic fever (Goldbach $\&$ Peters 1994). Tospoviruses infect a wide range of economically important vegetables, legumes and ornamental plants, and numerous weed species in subtropical and temperate regions in the world (Pappu et al. 2009).

Tospoviruses share similar virion structure with other bunyaviruses. The tripartite ssRNA genome is encapsidated by a lipid envelop forming pleomorphically spherical particles (80-120 nm diameter). The genome consists of three RNA molecules referred to as large (L),

*Corresponding author: shirani@bot.ruh.ac.lk medium (M) and small (S) (Nichol et al. 2005). The L RNA has a negative-sense nature encoding the RNA-dependent RNA polymerase (RdRp), while the M and S RNAs are ambisense (de Haan et al. 1990; de Haan 1991). The $M$ segment encodes a precursor of the two glycoproteins, the $G_{C}$ and $G_{N}$ proteins on the lipid envelop, in the viral complementary sense and a non-structural protein $\left(\mathrm{NS}_{\mathrm{M}}\right)$ in a viral-sense RNA which is involved in cell-to-cell movement of the virus within its plant host (Kormelink et al. 1992). The S RNA encodes nucleocapsid $(\mathrm{N})$ protein in the viral complementary sense and a non-structural protein $\left(\mathrm{NS}_{\mathrm{S}}\right)$ in the viral sense which has a function as suppressor of RNA silencing (HassaniMehraban et al. 2010).

The tospoviruses are transmitted by thrips (Thripidae, Thysanoptera) in a circulativepropagative manner (Ullman et al. 1993;Wijkampet al. 1993).Out of the estimated 5,000 thrips species, only 14 species are known as potential tospovirus vectors. Most of vectors belong to the genera Frankliniella and Thrips (Riley et al. 2011). Species in the genus Frank- 
liniella have a neotropical distribution of which majority of species are considered to be endemic to the Americas (Nakahara 1997). The vectors, $F$. occidentalis and $T$. tabaci, have a worldwide distribution (Mound 2002).

Until 2009, nineteen tospovirus species have been described, of which eight are accepted as confirmed species by the ICTV, while the rest are considered as tentative species (Pappu et al. 2009). Recently, the tospovirus species list expanded up to 24 species with the identification of Alstroemeria necrotic streak virus (ANSV) from Colombia infecting Alstroemeria sp. (Hassani-Mehraban et al. 2010), Tomato necrotic rings pot virus (TNRV) infecting tomato in Thailand (Seepiban et al. 2011),Pepper necrotic spot virus from Peru (Torres et al. 2012), Soybean vein necrosis-associated virus from United States (Zhou et al. 2011)and Bean necrotic mosaic virus from Brazil (de Oliveira et al. 2011).The major descriptor used to demarcate a new tospovirus species is its $\mathrm{N}$ protein amino acid sequence identity with previously reported sequences (Hassani-Mehraban et al. 2010). Other descriptors such as vector specificity, serology and host range (Reddy et al. 1995) form additional markers. Strains of the same species have a higher amino acid residues identity than $90 \%$ in their $\mathrm{N}$ proteins, and members of distinct species have a lower identity than $90 \%$ (Nichol et al. 2005).

The geographical delineation of tospoviruses is clustered into an Euro-Asian and an American's cluster based on their $\mathrm{N}$ protein amino acid sequence phylogeny (Voinnet et al. 2000; Cortes et al. 2001; Gibbs 1995). To date, 15 species are identified from the Asian continent. The greatest diversity in tospoviruses occurs in South-East Asia infecting a wide range of crop species. Tomato spotted wilt virus (TSWV), the type species of the genus Tospovirus is geographically the most widely distributed species within this genus. However, in Asia, TSWV has only been reported from some countries such as Japan, Korea, Israel, Middle East, Taiwan (Pappu et al. 2009) and Indonesia (Damayanti \& Naidu 2009). Groundnut bud necrosis virus (GBNV), although first consid- ered to be TSWV, has been reported to cause severe economic losses in groundnut, tomato, potato and soybean in many Asian countries (Reddy et al. 1995). In addition of GBNV, four other tospoviruses are known to occur in India, i.e. Capsicum chlorosis virus $(\mathrm{CaCV})$, Groundnut yellow spot virus (GYSV), Irish yellow spot virus (IYSV), and Watermelon bud necrosis virus (WBNV) (Mandal et al. 2012). In addition, several other tospoviruses such as Melon yellow spot virus (MYSV), Tomato necrotic ring spot virus, Watermelon silver mottle virus (WSMoV) and Chrysanthemum stem necrosis virus (CSNV) are reported from South -East Asia causing diseases in vegetables and ornamentals (Pappu et al. 2009). In Sri Lanka, IYSV infecting leek has recently been reported (Widana Gamage et al. 2010) being the first species using PCR and phylogenetic analysis in its identification. This isolate shows a 97\% protein identity with the Dutch strain (IYSVNL) and $92 \%$ with the Brazilian strain (IYSVBR). Earlier in 1988, TSWV has been reported infecting groundnut (Arachis hypogaea). Its identification was based on the symptoms produced on Petunia hybrida, known to cause local lesions specific for TSWV and all other tospoviruses, thrips transmission studies and serology (Jayasena et al. 1988). These properties were the only tools that could be used to identify an infection with TSWV; at that time the only representative of a monotypic virus group. High-quality antisera became available for the detection of tospoviruses, during the ear1y1990s (de Avila et al. 1993b; Reddy et al. 1995). Later, data from serological comparative studies and subsequently from sequencing of nucleic acids revealed the existence of several distinct tospoviruses (German et al. 1992: de Ávila et al.1993a). One example of such an understandable misidentification was made in the identification of the pathogen of a disease in groundnut as being caused by TSWV (Ghanekar et al. 1979; Amin et al.1981; Reddy et al. 1991). Reddy et al.(1995) identified this pathogen as a new tospovirus named Peanut bud necrosis virus (now known as GBNV) in India and was later also detected in other South -East Asian countries. Hence, the identification of TSWV infecting groundnut in Sri Lanka as 
early as 1988 needs to be confirmed with sequence data. However, no information is available in the previous report (Reddy et al. 1995) or any other report on the identification of GBNV in Sri Lanka except the occurrence of bud necrosis disease. To date, no gene sequence data is available on tospoviruses in Sri Lanka except the $\mathrm{N}$ protein gene sequence of IYSV (Accession No. GU901211) deposited in the NCBI/Genbank (Widana Gamage et al. 2010). Further, to our knowledge an islandwide screening has not yet been done on the incidence of tospoviruses and no data on the thrips vector species have been collected so far. But it will be likely that some of the species prevailing in South-East Asia will also available in Sri Lanka. Hence, the primary objective of this study is to identify tospoviruses infecting economically important crop plants in Sri Lanka and to determine its phylogenetic position among the known tospovirus species.

\section{MATERIALS AND METHODS}

Samples were collected from plants showing characteristic symptoms of tospovirus infections on plants of different crop species grown in open fields during June-August in 2009 in the Southern, Central, Uva and North-central provinces where most of the vegetable crops are grown. Plants were sampled when they were suspected to be infected with a tospovirus on the basis of symptoms on leaves and fruits. Collected samples were kept on ice in the field in order to prevent rapid desiccation due to the high prevailing temperature $\left(32^{\circ} \mathrm{C}\right)$.

Young leaves with clear symptoms were cut into 3-4 mm wide strips and placed in Petri plates on top of a layer of anhydrous Calcium chloride $\left(\mathrm{CaCl}_{2}\right)$. Leaf material and $\mathrm{CaCl}_{2}$ were separated by a filter paper. The Petri plates were tightly closed with parafilm and placed in a refrigerator $\left(4^{\circ} \mathrm{C}\right)$. After 2 days, the dried crispy leaf material was transferred into a tube. Tubes were filled from bottom to top with subsequent layers consisting of anhy- drous $\mathrm{CaCl}_{2}$, a small plug of cotton wool, dried leaf material, a small plug of cotton wool, and finally a small amount of anhydrous $\mathrm{CaCl}_{2}$. Tubes were sealed with parafilm wrapped around the lid and stored at $-80^{\circ} \mathrm{C}$. Samples containing dried leaf materials sealed in plastic bags were brought to the laboratory of Virology, Wageningen, for further studies.

Crude virus extracts were prepared by grinding dried leaf material in $1 \times$ PBS buffer

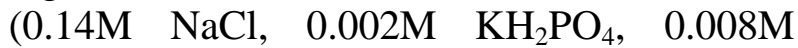
$\mathrm{Na}_{2} \mathrm{HPO}_{4} .2 \mathrm{H}_{2} \mathrm{O}, 0.002 \mathrm{M} \mathrm{KCl}, 0.003 \mathrm{NaN}_{3}$ at $\mathrm{pH}$ 7.4) and mechanically inoculated onto carborandum powder dusted leaves of Nicotiana benthamiana in order to recover and propagate viruses. All samples that were able to infect $N$. benthamiana were subsequently inoculated onto Petunia hybrida, which produces dark brown local lesion within two to three days after inoculation (Brunt 1959). Samples which were able to infect both $N$. benthamiana and $P$. hybrida were used in further analysis. The selected isolates and other tospoviruses used in this study were maintained in $N$. benthamiana. However, mechanical serial passages over maintenance hosts were limited to maximum four passages in order to prevent the generation of defective intermediates (Inoue-Nagata et al. 1997). Inoculated plants were placed for symptom development in the greenhouse at $25^{\circ} \mathrm{C}$ under normal day-light conditions and in winter additional light was given.

Virus extracts of systemically infected $N$. benthamiana plants were serologically compared with other tospovirus species by DAS-ELISA (Clark \& Adams 1977) after slight modifications, using polyclonal antisera directed against $\mathrm{N}$ protein of each virus tested. Microtitre plates were coated with immuno-gamma globuline (IgG) $(1 \mu \mathrm{g} / \mathrm{ml})$ of TSWV, Tomato chlorotic spot virus (TCSV), GBNV, Groundnut ring spot virus (GRSV), MYSV, WSMoV, Tomato yellow ring virus (TYRV) and IYSV. Un-occupied sites in IgG coated wells were blocked with $2 \%$ Elk (dried 
skimmed milk) dissolved in $1 \mathrm{x}$ PBS in order to prevent any a-specific protein attachment. Virus sap extracts were prepared by macerating $0.03 \mathrm{~g}$ of systemically infected leaves in 1 $\mathrm{ml}$ of 1x PBS-Tween-20. Subsequently, IgG conjugated with alkaline phosphatase was added as a secondary antibody $(1 \mu \mathrm{g} / \mathrm{ml})$ to the plate. Finally, when the substrate pnitrophenyl phosphate $(1 \mu \mathrm{g} / \mathrm{ml})$ in substrate buffer (96 ml diethanolamine, $600 \mathrm{ml}$ Mili Q, $0.003 \mathrm{M} \mathrm{NaN}_{3}$ at $\mathrm{pH} 9.8$ ) was added. Plates were incubated at $37^{\circ} \mathrm{C}$ or at room temperature. The development of yellow colour due to the release of the phosphate group from the substrate indicates the presence of the virus to be detected. Absorbances were measured at $\mathrm{A}_{405 \mathrm{~nm}}$ using a FLUOstar OPTIMA (BMG LABTECH GmbH, Offenburg, Germany). ELISA readings were made $30,60,90$ and/or 120 min of incubation. A sample was considered positive when the $A_{405 n}$ value was higher than the average of the healthy value plus three times the standard deviation.

The results obtained in DAS-ELISA were confirmed by RT-PCR. Total RNA was extracted from systemically infected $N$. benthamiana leaves using TRIzol® method (Invitrogen) according to the manufacturer's protocol. The nucleocapsid genes were reversely transcribed by AMV (HC) reverse transcriptase (Promega Corporation, USA) using primers specific for TSWV (Table 1) and GBNV. The primer combinations used in first strand cDNA synthesis were also used in PCR.

Table 1.Primers used to amplify $\mathbf{N}$ gene TSWV. Non-viral sequences are indicated in bold fase

\begin{tabular}{ll}
\hline Primer & sequence 5' to 3' \\
\hline T S W V & CCCGGATCCATGTCTAAGGTTAAGCTCACTAAGG \\
start p19 & \\
T S W V & CCCGGATCCTCAAGCAAGTTCTGCGAGTTTTG \\
stop p15 & \\
\hline
\end{tabular}

The resulting PCR amplicons with an expected size ( $800 \mathrm{bp})$ were analysed on $1 \%$ agarose gels and extracted using home-made columns (Borodina et al.2003) prepared by silica membranes cut out from GF/F borosilicate glass fibre paper (Whatmann ${ }^{\mathrm{TM}}$, England) and cloned into pGEM-T easy (Promega Corporation, USA) vector system. Ligations were transformed into E. coli (DH5 $\alpha$ ) competent cells by electrophoration. Recombinant plasmids were purified using home-made columns (Borodina et al.2003) with slight modifications and digested with Notl restriction enzyme. Presence of cloned fragments was checked on $1 \%$ agarose gels. Plasmids containing expected size inserts were sequenced. Obtained sequences were compared (BLAST) with sequences available in NCBI/GenBank.

\section{RESULTS AND DISCUSSION}

Samples were collected from different vegetable crops showing symptoms resembling of those caused by tospoviruses as could be judged from pictures on the internet. However, it was difficult to distinguish between tospovirus infections and infections by any other virus by visual inspection only.

Tomato (var. Thilina) showing characteristic TSWV symptoms of necrotic spots surrounded by concentric rings or ring spots on leaves and fruits (Fig 1 A, B) were observed in Ambalantota in Southern, and Gannoruwa in Central Provinces. Severe stunting of plants associated with bud necrosis, axillary shoot proliferation and brownish rust on leaves (Fig $1 \mathrm{C}, \mathrm{D}$ ) were observed in groundnut (var. Walawa) in Angunakolapalassa in Southern Province. The symptoms of groundnut resemble those as described by Reddy et al. (1995). However, the symptoms caused by TSWV and GBNV on groundnut cannot be distinguished from each other or with difficulties. In addition, severe chlorosis and irregularly shaped chlorotic eye-like spots surrounded by distinct margins were also observed on leaves. 
Most of the cucurbits including watermelon were found to be heavily infected with one or more viruses in several fields but, did not resemble to any characteristic tospovirus-like symptoms. No any cucurbit sample gave a positive response on $N$. benthamiana indicating that none of the samples were infected with Cucumber mosaic virus. As an advice for further studies, cucumber seedlings have to be used to isolate possibly infecting viruses. Severe damages caused by thrips feeding were observed on onion and leek leaves in several fields in major growing areas. These observations lead us to look for possible IYSV infection in onion and leek. Typically, IYSV infection results in local chlorotic spots and diamond shaped lesions on leaves. Of the onion samples showing local chlorotic spots, we were not able to detect IYSV infection. However, IYSV infection was detected in leek showing diamond shaped lesions on leaves. Often, in both onion and leek, thrips damages on leaves were observed larger than the damage that could be caused by IYSV.

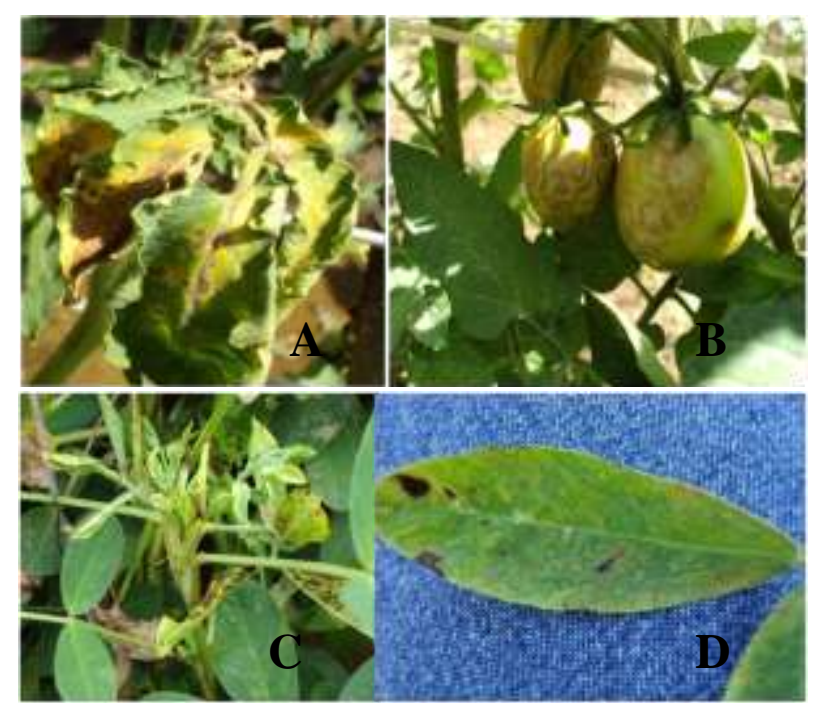

Fig1.Tomato spotted wilt virus on tomato (A and B) and groundnut ( $C$ and $D)$. A-necrotic lesions on leaves, B- brownish concentric rings on fruits of tomato, C- bud necrosis, axillary shoot proliferation and brownish rust on the leaves, D-chlorotic eyelike spots on a leaf of groundnut.
Viruses were recovered on mechanically inoculated $N$. benthamiana plants. Inoculated plants showed chlorotic spots on locally infected leaves after three to four days of inoculation while systemic infections were observed after one week. Three of the isolates that were able to systemically infect $N$. benthamiana plants were also able to produce necrotic local lesions on P.hybrida. Samples which produce necrotic lesions on inoculated leaves of P.hybrida can be considered infected with a tospovirus, as the local lesions appearing within three days given as indication of a tospovirus infection. Accordingly, two tomato samples from Ambalantota and Gannoruwa and a groundnut sample from Angunakolapalassa were found to be infected with tospoviruses and selected for further characterization.

All the three isolates were serologically positive for TSWV infections in DAS-ELISA, whereas no positive reactions were obtained with GBNV antiserum. Serological crossreactions with GRSV and TCSV polyclonal antisera were also positive with lower signals as shown by de Ávila et al. (1993b), indicating that isolates were closely related to TSWV and not to GRSV and TCSV.

RT-PCR reactions with TSWV specific primers (Table 1) for its entire $\mathrm{N}$ gene amplified around $800 \mathrm{bp}$ fragments corresponding to the size of the TSWV N gene (Figure 2). These RT- PCR results confirmed that the tomato and groundnut plants in the field were certainly infected with TSWV. No amplification was given with GBNV specific primers.

The sequences of tomato and groundnut isolates compared with other available TSWV N gene sequences in the Genbank showed a $98 \%$ protein identity to the $\mathrm{N}$ gene of Brazilian isolate (BR-01). The non-identical amino acid residues of the tomato TSWV isolate which differed from the BR-01 isolate, also differed from the groundnut isolate. The complete sequences of TWSV $\mathrm{N}$ gene of tomato 
and a partial sequence TSWV $\mathrm{N}$ gene of groundnut have been deposited at NCBI/ GenBank under accession numbers HM231305, HM231307 and HM231306respectively. To our knowledge, previously reported serological detection of TSWV infecting groundnut in Sri Lanka (Jayasena et al.1988) might have been a mis-identification due to the use of inadequate tools to discriminate the different tospoviruses species. Therefore, we cannot exclude that the latter authors would have been working with GBNV as the virus they analysed was isolated from groundnut, probably the most prevailing tospovirus on groundnut.

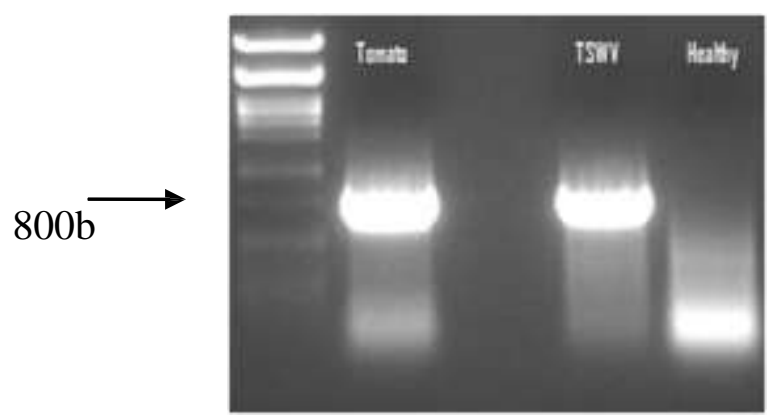

Fig2. RT-PCR showing bands amplified ( $\sim 800$ bp) with TSWV specific primers. $L_{1}$ : Lambda DNA ladder (Pst1), $\mathrm{L}_{2}$ : Tomato isolate, $\mathrm{L}_{3}$ : TSWV BR-01 strain (positive control) and $\mathrm{L}_{4}$ : healthy $N$. benthamiana (negative control)

Although TSWV was found infecting only tomato and groundnut so far in Sri Lanka, its natural host range may expand in the future with extended survey thought out the island since TSWV is known to infect more than 900 plant species worldwide (Pappu et al. 2009). It is important to point out that our samples were collected from a limited number of crop species from some fields in our crop growing regions. No samples were collected from ornamental or weed plant species.

Further, no data have been collected on the thrips vector population transmitting either TSWV or IYSV in Sri Lanka. Although $F$. occidentalis is the principal vector of TSWV, this virus can also be transmitted by several other thrips species including T. tabaci which is the only vector of IYSV but may transmit TSWV as well and probably the other viruses prevailing in South-East Asia (Riley et al. 2011). Due to the inadequate sample collection representing whole crop range and growing regions in Sri Lanka, and the absence of data on vector prevalence, abundance or damage caused by vectors, we cannot conclude that only two tospoviruses; TSWV and IYSV are pathogens of Sri Lanka. It is highly possible that other tospoviruses prevailing in South -East Asia might also available in Sri Lanka infecting various crops, ornamental and weed species.

Tospoviruses are becoming an emerging problem in the agriculture sector of many countries like Bangladesh, India, Nepal, Pakistan and Sri Lanka in the Indian sub-continent (Mandal et al. 2012). Systematic and regular surveys for disease identification, indexing and controlling of transmitting vectors although helps to some extent in controlling the virus to minimize the present and future economic impact, survival of the virus between crops has also to be understood. In addition, regular monitoring for the species crossing borders through international trade is considered prime importance.

\section{CONCLUSION}

The present study confirms presence of three isolates of TSWV infecting tomato and groundnut in Sri Lanka. Further, the identified TSWV isolates were found closely related $(98 \%)$ to the Brazilian isolate (BR-01) according to the $\mathrm{N}$ gene phylogeny. This is the first report providing $\mathrm{N}$ gene sequence data of TSWV isolates infecting crops in Sri Lanka.

\section{REFERENCES}

Amin PW, Reddy DVR,Ghanekar AM and Reddy MS 1981 Transmission of tomato spotted wilt virus, the causal agent of bud necrosis of peanut, by Scirtothrips dorsalis and Frankliniella 
schultzei. Plant Disease 65: 663-665.

Borodina T, Lehrach H and Soldator A 2003 DNA purification on homemade silica spin columns. Anal.Biochem. 321: 135-137.

Brunt AA 1959 Leaf enations in Dahlia variabilis Desf., induced by tomato spotted wilt virus. Nature 183: 627-628.

Clark MF and Adams AN 1977 Characteristics of the microplate method of enzyme-linked immunosorbent assay for the detection of plant viruses. J. Gen. Virol.34:475-483.

Cortês I, Saaijer J, Wongjkaew KS, Pereira AM, Goldbach R, Peters D and Kormelink R 2001 Identification and characterization of a novel tospovirus species using a new RT-PCR approach. Arch. Virol.146: 265-278.

Damayanti TA \& Naidu RA 2009 Identification of Peanut bud necrosis virus and Tomato spotted wilt virus in Indonesia for the first time. New Disease Reports 19(6).

de Ávila AC, de Haan P, Kormelink R, Resende RO, Goldbach RW and Peters D 1993a Classification of tospoviruses based on phylogeny of nucleoprotein gene sequences. J. Gen. Virol. 74: 153-159.

de Ávila AC, de Haan P, Smeets MLL, Resende RO, Kormelink R, Kitajima EW, Goldbach RW and Peters D 1993b Distinct levels of relationships between tospovirus isolates. Arch. Virol. 128: 211-227.

de Haan P, Wagemakers L, Peters D, Goldbach R 1990 The S RNA segment of tomato spotted wilt virus has an ambisense character. J. Gen.Virol. 71:1001 -1007 .

de Haan P, Kormelink R, Resende RO, van Poelwijk F, Peters D, Goldbach R 1991 Tomato spotted wilt virus L RNA encodes a putative RNA polymerase. J. Gen.Virol. 71:2207-2216.

de Oliveira AS, Machado Bertran AG, InoueNagata AK, Nagata T, Kitajima EW et al. 2011 An RNA-dependent RNA polymerase gene of a distinct Brazilian tospovirus. Virus Genes 43: 385-389.

German TL, Ullman DE and Moyer JW 1992

Tospoviruses: diagnosis, molecular biology, phylogeny and vector relationships. Ann. Rev.Phytopathol. 30:315-348.

Ghanekar AM, Reddy DVR, lizuka N, Amin PW \& Gibbons RW 1979 Bud necrosis of groundnut (Arachishypogaea) in India caused by tomato spotted wilt virus. Ann. appl. Biol. 93: 173-179.

Gibbs M 1995 The luteovirus super group: rampant recombination and persistent partnerships. pp 351-368. In: Gibbs AJ, Calisher CH, Garcia-Arenal F (eds) Molecular basis of virus evolution. Cambridge University Press. Cambridge.

Goldbach R and Peters D 1994 Possible cause of the emergence of tospovirus disease. Seminars in Virology 5: 113-120.

Hassani-Mehraban A, Botermans M, Verhoeven JThJ, Meekes E, Saaijer J, Peters D, Goldbach R and Kormelink R 2010 A distinct tospovirus causing necrotic streak on Alstroemeria sp. in Colombia. Arch. Virol. 155: 423-428.

Inoue-Nagata AK, Kormelink R, Nagata T, Kitajima EW, Goldbach R and Peters D 1997 Effects of temperature and host on the generation of tomato spotted wilt virus defective interfering RNA's. Phytopathology 87: 1168-1173.

Jayasena KW, Rajapakse RHS and Reddy DVR 1988 First report of Tomato spotted wilt virus infecting peanut in Sri Lanka. Plant Disease 72: 912.

Kormelink R, de Haan P, Meurs C, Peters D and Goldbach R 1992 The nucleotide sequence of the M RNA segment of tomato spotted wilt virus, a bunyavirus with two ambisense RNA segments. J. Gen.Virol. 73:2795-2804.

Mandal B, Jain RK, Krishnareddy M, Krishna Kumar NK, Ravi KS and Pappu HR 2012 Emerging Problems of Tospovi- 
ruses (Bunyaviridae) and their Management in the Indian Subcontinent. Plant Disease 96 (4).

Mound LA 2002 The Thrips and Frankliniella genus groups: the phylogenetic significance of ctenidia.pp 379-386. In: Marullo $\mathrm{R}$ and Mound LA(eds.)Thrips and Tospoviruses. Proceedings of the 7th International Symposium on Thysanoptera. Australian National Insect Collection, Canberra.

Nakahara S 1997 Annotated list of the Frankliniella species of the world (Thysanoptera :Thripidae) Contributions on entomology international. Associated Publishers.

Nichol ST, Beaty B, Elliott RM, Goldbach R, Plyusnin A, Schmaljohn AL, Tesh RB 2005 Bunyaviridae. pp 695-716. In: Fauquet CM, Mayo MA, Maniloff J, Desselberger U and Ball LA (eds) Virus taxonomy: eighth report of the International Committee on taxonomy of viruses. Elsevier Academic Press.

Pappu HR, Jones RAC and Jain RK 2009 Global status of tospovirus epidemics in diverse cropping systems: Successes achieved and challenges ahead. Virus Research 141: 219-236.

Reddy DVR, Wightman JA, Beshear RJ, Highland B, Black M, Sreenivasulu P, Dwivedi SL, Demski JW, McDonald D, Smith JrJW and Smith DH 1991 Bud necrosis: a disease of groundnut caused by tomato spotted wilt virus. Information Bulletin no. 31.International Crops Research Institute for the SemiArid Tropics,Patancheru502 324, Andhra Pradesh, India.

Reddy DVR, Buiel AAM, Satyanarayana T, Dwivedi SL, Reddy AS, Ratna AS, Vijaylakshmi K, Ranga Rao GV, Naidu RA and Wightman JA 1995 Peanut bud necrosis virus disease: an overview. pp 3-7. In: Buiel AAM, Parlevliet JE, Lenne JM (eds.) Recent Studies on Peanut bud necrosis dis-
ease.Proceedings of a Meeting. March 20, 1995.ICRISAT Asia Centre.

Riley DG, Joseph SV, Srinivasan R and Diffie S 2011 Thrips Vectors of Tospoviruses. J. Integ. Pest Mngmt.1 (2).

Seepiban C, Gajanandana O, Attathom T and Attathom S 2011 Tomato necrotic ringspot virus, a new tospovirus isolated in Thailand. Arch.Virol. 156:263 -274 .

Torres R, Larenas J, Fribourg C and Romero J 2012 Pepper necrotic spot virus, a new tospovirus infecting solanaceous crops in Peru. Arch.Virol. 157:609-615.

Ullman DE, German TL, Sherwood JL, Westcot DM and Cantone FA 1993 Tospovirus replication in insect vector cells - immunocytochemical evidence that the nonstructural protein encoded by the s-rna of tomato spotted wilt tospovirus is present in thrips vector cells. Phytopathology 83: 456-463.

Voinnet $\mathrm{O}$, Lederer $\mathrm{C}$ and Baulcombe DC 2000 A viral movement protein prevents spread of the gene silencing signal in Nicotiana benthamiana. Cell 103: $157-167$.

Widana Gamage SMK, Hassani-Mehraban A and Peters D 2010 Identification of Iris yellow spot virus on Leek (Allium porrum) in Sri Lanka. Plant Disease 94: 1070-1070.

Wijkamp I, Vanlent J, Kormelink R, Goldbach R and Peters D 1993 Multiplication of tomato spotted wilt virus in its insect vector, Frankliniella occidentalis. J. Gen.Virol. 74: 341-349.

Zhou J, Kantartzi SK, Wen RH, Newman M, Hajimorad MR et al. 2011 Molecular characterization of a new tospovirus infecting soybean. Virus Genes 43: 289-295. 